\title{
Dancing around the Cauldron with Rangda, the Balinese widow-witch: Exploring gender relations and attitudes toward women and children in Southeast Asia
}

\section{Menari di tepi kawah dengan Rangda, penyihir janda Bali: Eksplorasi relasi gender dan perilaku terhadap perempuan dan anak di Asia Tenggara}

\author{
Kathleen Nadeau \\ Department of Anthropology, California State University, San Bernardino \\ Address: 5500 University Parkway, San Bernardino, California 92407, United States of America \\ E-mail:knadeau@csusb.edu
}

Article History: Received 16 June 2020; Accepted 11 October 2020; Published Online 3 November 2020

\begin{abstract}
By taking a cross-cultural approach based on library research, content analysis, and fieldwork in the Philippines, this paper compares Southeast Asian and European tales. The Southeast Asian tales are rooted in local philosophical and cultural traditions. Balinese literature is replete with descriptions of rituals to ward off vampires. The flying half-bodied Aswangs in the Philippines, like their Malaysian sisterlings, can be shown to bear some resemblance to Balinese witches who culminate in the Rangda, the queen of witches. The Balinese ritual battle between the troubled widow witch Rangda and the gentle Barong offers a circular view of history that arguably holds to a universal notion of good and evil. In contrast, European witch tales can be traced back to the hysterical witch hunts and persecution of female midwives and healers in Medieval times that were perceived as threatening the power and authority of male doctors, priests, and landed government officials. The conclusion is that Southeast Asian lore connotes a different set of gender relations and attitudes toward women and children than European origin.
\end{abstract}

Keywords: Aswangs, Balinese child-rearing rituals, cultural identity, gender constructs, witchlore

\begin{abstract}
Abstrak
Dengan mengambil pendekatan lintas budaya berdasarkan studi literatur, analisis konten dan penelitian lapangan di Filipina, artikel ini membandingkan cerita rakyat tentang penyihir Asia Tenggara dengan kisahkisah penyihir Eropa. Kisah-kisah ini telah lama mengakar pada tradisi filosofis Asia Selatan dan Tenggara kuno dan meliputi aspek kehidupan sosial masyarakatnya. Sastra Bali sarat dengan deskripsi ritual untuk mengusir vampir. Aswang digambarkan memiliki tubuh setengah terbang di Filipina, serupa dengan saudara perempuan Malaysia mereka, yang memiliki kemiripan dengan sosok ratu penyihir Bali, dikenal dengan Rangda. Pertarungan ritual Bali Rangda yang digambarkan sebagai sosok yang bermasalah dan Barong yang lembut menawarkan perspektif sejarah yang berpegang pada gagasan universal tentang hal yang baik dan jahat. Sebaliknya, kisah penyihir Eropa dapat ditelusuri kembali ke perburuan penyihir, penganiayaan terhadap bidan dan tabib wanita di Abad Pertengahan yang dianggap mengancam kekuasaan dan otoritas dokter, pendeta, dan pejabat pemerintah setempat. Penelitian ini menyimpulkan bahwa kisah rakyat di Asia Tenggara berkonotasi dengan hubungan dan sikap gender yang berbeda terhadap perempuan dan anak-anak dibandingkan dengan kisah-kisah yang berasal dari Eropa.
\end{abstract}

Kata kunci: Aswang, ritual mengasuh anak Bali, identitas budaya, konstruksi gender, kisah penyihir

\section{Introduction}

In pre-modern times, mythology was a program for action. Myths were ritualized and not understood unless the people prepared to change (Armstrong 1994). The ancients knew that myths were more than history. They were stories relaying the meanings of timeless and circular truth, something repeated throughout human history in different guises. The stories are usually imparted in the course of an initiation rite of passage such as Balinese tooth-filling. A traditional ritual intended to separate humans and gods from animals and demons by filling down two (animal-looking) pointed incisors to drive out bad vices such as greed or jealousy while cultivating compassion and gentility (Smith 2018). 
While Balinese mythology may be acted out to entertain tourists, this paper in ritual theater only for the show to entertain tourists, this paper concerns the myth of Barong and Rangda as a ritual for change, bringing in the good by driving out the bad (Picard 1990). Performed through music, song, and dance in tandem with other art forms such as the wayang kulit (shadow puppet theater), paintings, sculptures, and architecture, the Balinese ritual and mythic performances primarily derive from the great Hindu epics of ancient India. They are used and adapted to the local society to promote Balinese ideas and culture (Lansing 1995, Phalgunadi 1991). Bali's ritual performance and musical dance continue to play a formative role in the family and community in child-rearing practices today. European witch stories ritually enacted when children dress up as witches and other goblins on Halloween may offer some social catharsis; however, content analysis reveals that the various witch tales coming from this world region have more to do with the attitudes towards women than child development.

\section{Research Method}

The paper is based on the author's library research, fieldwork in the Philippines (1992-1994, 2000, 2008, and 2015), and a content analysis of select witch stories derived from particular cultural and regional contexts. It examines some of the etiological roots, transmissions, and development of culturally specific witchlore and the associated cultural constructions of gender and identity from a comparative and anthropological perspective (Nadeau 2011). The paper begins with a comparative analysis of some of the common motifs found in culturally-diverse Southeast Asian witch stories (Rangda, the Balinese widow witch, Philippine Aswangs, and Malaysian Penanggalans), it then compares them to West European witch tales. The conclusion is drawn that Southeast Asian witch tales connote a different set of gender relations and attitudes towards women and children than Western European origin.

Lansing (1995) \& Parker (2002) wrote extensively about the Balinese ritual battle between the forces of good and evil that occurred between the panther-like guardian called Barong and a witch-like creature called Rangda (Abrams \& Ambrosino 1979). She had an elongated tongue and flew around at night to suck the blood of her victims. Rangda, with her long lolling tongue and skulls of children hanging around her head, at first look, bears a striking resemblance to the viscera-sucking flying half-bodied Aswangs (witches) of the Philippines and Penanggalans (witches) in Malaysia. Is there a more profound connection bringing these different witch tales together in a common theme?

In Bali, witches seem to represent the many forces of vice in the world. The Balinese still perform rituals to change potentially dangerous and chaotic witch-like forces into virtuous behavioral and social actions. These transformative ancient rituals acted out in song, music, and dance continue today. They are creatively modified and adapted from classical Hindu epics such as the great Mahabharata and Ramayana tale. For example, the story about the five good-hearted Pandava brothers fighting the pre-mortal war against their power-lusting cousins, the Kauravas, in Mahabharata's excellent adventure story. They offer an alternative interpretation of the relationship between Rangda, the witch, and her arch-foe, the gentle Balinese Barong or spirit brother. Could the five Pandava brothers be interchangeable with the five Balinese spirit guardians, such as the Barong in his four emanations standing watch at the North, South, East, and West corners of a village, or symbolically represent the Balinese child's spirit siblings. If they accompany birth and are appropriately honored, the four spirit siblings will help a developing child transform potential evil influences into good. When a child is born in Bali, he or she is said to have four spiritual siblings that manifest physically as the placenta, the water, the vernix caseosa, and the blood, which form one child (Darmini 2013). At the village level, it believed that four spirit guardians (barongs) stand to watch at each of the four cardinal directions - North, South, East, and West - with one at the center point.

The Balinese Barong, like a human being from the Balinese cultural perspective, might represent the culmination of the four spirit children who accompany a human child throughout his or her lifetime. According to the film narrated by anthropologist Stephen Lansing specializing in Indonesian Studies, the Three Worlds of Bali (Abrams \& Ambrosino 1979), it is to the spirit siblings that ritual offerings are made at each turning point in their life cycle, such as the first time that a child steps 
on the ground, their first haircut or on a birthday. There are also offerings made to the five cardinal directions of North, South, East, West, and Center, with the center being the culmination with each spirit child representing a different cardinal direction culminating in the center. It is to the spirit children to whom all Balinese ritual offerings are made concerning a person's life span. The Balinese person's spirit siblings are honored at crucial turning points such as the child's 100 day birthday, coming of age ceremonies, marriage, and death. The latter begins a person's journey into life, for the Balinese believe in reincarnation. From this perspective, a child being taken over by witches could be tantamount to a child succumbing to worldly vices where the spirit siblings, once honored and controlled, reflect what it means to be a model human being.

Philosophically, some of the moral lessons enacted in the Rangda versus Barong battle are similar to the teachings found in the Hindu story of Arjuna's battle with his 100 rambunctious cousins as narrated in the great epic adventure of the Mahabharata in The Bhagavad-Gita. Briefly, the Mahabharata is a story about five brave and virtuous princes who married one beautiful princess. The five Pandava princes, fatherless in childhood, grew up together with one hundred rambunctious cousins. The Pandavas were born of the Gods while their 100 cousins emerged from an earthen jar, which, like clay, symbolizes human beginnings. As a young man, the eldest cousin succumbed to feelings of jealousy and greed. He wanted to be crowned king instead of Yudhisthira, the rightful heir and eldest of the Pandava brothers. The cousin raised an army to challenge the Pandavas for the throne. One of the Pandava brothers, Arjuna, the perfect and righteous warrior, tried all peaceful means to compromise with this cousin; however, it was naught. Without recourse, Arjuna dejectedly went into battle with his army against his relatives. There are many symbolic meanings in this great epic adventure of humankind. For example, there are 100 cousins. It points not only to the 100 named Hindu vices (Lansing 1995:35) and the idea that there is strength in numbers; however, the Mahabharata's moral is not might; however, goodness. In the end, goodness reigns over evil. Could the five virtuous brothers in the Mahabharata be equivalent to the five spirit siblings who watch over Balinese children and guard over village life? Could Rangda and the Aswang witches, like the 100 cousins in India's epic, represent those who succumb to worldly vices? Is it possible that there is a general philosophical connection between the stories of vampire's heads afloat in diasporic Indonesian, Malaysian, and Philippine communities? If so, what can we learn about the deeper meaning of the Aswangs and what it means to be a culturally gendered human being as used in contemporary local storytelling? What does a comparative study of witchlore reveal about how women and children are looked at on Southeast Asia islands compared to Europe?

\section{Results and Discussion}

This section explains the different attitudes towards women and children exhibited in Southeast Asian witch tales and rituals compared to European witchlore. It begins with a historical overview of witchlore in Southeast Asia by selecting ethnographic examples followed by a discussion on the characteristics of the differences exhibited by European witch tales in contrast to those of Southeast Asia.

Before the colonial period in South and Southeast Asia, the geographical boundaries separating countries as we know them today were not in place (Reid 1988, Reid 2015). The boundaries were fluid, and people's constant movement as local leaders vied to gain a following around which vibrant centers of trade and power emerged. In ancient times (around AD 1000-1200), the Philippines, Indonesia, and Malaysia were nearby and familiar with their oral and written traditions. They were not demarked countries; however, somewhat fluid networks in the broader economy of trade and exchange. Around AD 1000-1200, they shared the same writing system derived from the Brahmin scripts of India (Diringer 1948). In Bali, Brahmin priests and scholars still read and write this old script, and in the ancient Philippines, this writing system was called Alibata (Diringer 1948:440441). Theoretically, the Philippine Aswang myth in all of its variant forms needs to be looked at in the broader context of Southeast Asia's maritime world in which it earlier surfaced; however, in the Philippines, early Spanish conquistadors and friars set out to destroy and thereby largely fragmented the many outward forms of pre-colonial religious practices and beliefs. Many may have been lost forever, although Filipinos passionately work to keep their richly diverse cultural heritage and 
traditional dances alive on stage; however, it did not occur in colonial Indonesia, where the Dutch were only interested in extracting the local resources for their benefit. Thus over time, Filipinos lost the important ritual details associated with the Aswang myth while the unarticulated subliminal meanings remain. It explains why some Filipino farmers still make rice offerings at the four corners of their village, just like Balinese farmers do so that the spirits will protect them, and when asked why the Filipino farmers cannot elaborate. When asked what the Aswang tales mean, they respond that they are just ghost stories (Nadeau 1993).

One possible way to get to the core of the myths associated with the Philippine Aswang may be to look at the Calonarang dance and musical performance. It is an exorcism of witches and demons in Bali, Indonesia (Bateson \& Mead 1942, Belo 1949, Lansing 1995, Parker 2002). Indonesians still have ready access to their cultural treasures in the form of ancient religious texts and paintings as they continue to be danced out in music and song. Lansing describes the Balinese Calonarang dance and musical performance as an exorcism of witches and demons that take place in Bali, Indonesia. Indonesia was colonized by the Dutch, whose only interest was extracting the local resources for their economic gain, not changing people's religion. It is why the ancient Calonarang ritual dance performance continues to be remembered. Lansing documents this ritual battle between the Barong, the village protector, and Rangda, the flying half-headed witch, as Lansing (1995) stated:

\begin{abstract}
"The Barong, to the Balinese, is the arch-foe of Rangda, the witch who controls black magic and delights in the feeding on corpses and the entrails of young children. They are the main characters in several religious dramas. The dramas consist of the two figures' encounter, from which ensues a battle that neither wins. In the course of the drama, the spiritual power (sakti) or soul (roh) of Barong and Rangda may enter their human impersonators, and spectators are often driven into trance by the mere sight of Rangda."
\end{abstract}

He takes us closer to understanding this ritual combat's hidden meaning between good and evil because he relates it to the 'inner' and 'outer' worlds of the Balinese. The playful, gentle, and robust Barong represents the village's guardian and all those who inhabit it. At the village level, he is the four spirit guards combined who stand watch over the community, each post to one of four cardinal directions and to whom ritual offerings of rice are made. By extension, at the individual level, the Barong is the culmination of the four spirit siblings who accompany each child at birth. These spirit siblings are the recipients of the sacred gifts at each of the crucial turning points in the span of a human lifetime. They are commissioned to help the child to grow into a good and virtuous human being. Hence, the gentle and fun-loving, however able, and robust Barong is the spirit protector who controls all of the world's vices.

In opposition, Rangda, the queen or culmination of approximately 100 witches that may correspond to known vices like anger, jealousy, and thievery, stirs up trouble. Lansing (1995) explains that the Balinese have names for more vices than outsiders are usually aware. Rangda is the daughter of Durga, one of the fiercest Devi forms of Hinduism. Devi is the Sanskrit term for the goddess. Ancient Hindu scripture indicates that all goddesses are ultimately the same goddess or Devi, and it is interesting to note that unlike the Christian vision of a solely male god who is untouched by sin, Hindu gods and goddesses contain within themselves emanations of both good and evil. A wellknown example is when Krishna encouraged Arjuna to take up arms against his 'flesh and blood' cousins who otherwise would forever wreak havoc on the world (Sargeant 1994). At its deepest root, there is only one god of which all others are emanations in Hinduism. Monaghan (1993) explains that Durga was the eldest female Devi in the primordial war between the gods and anti-gods. Her daughter, Rangda, is the one who sets loose the chaotic whirl of vices that tempt and torment the human spirit. She represents the unappeased, unfulfilled, and restless spirits who hover and cause havoc for the living. Parker (2002) reiterates the story of Rangda:

"The widow had a beautiful daughter who was of marriageable age; however, because of the widow's reputation for knowledge of sorcery, there were no suitors for her daughter's hand. Furious, the widow took up her book, a palm leaf manuscript of magic invocations, 
which had been granted her as a boon by the Goddess of Destruction, Durgha, and went to a graveyard with her entourage of half a dozen young women. Dancing with her entourage of trainee witches, Rangda asked the Goddess Durgha for permission and power to ruin the country and its people. Durga agreed; however, he requested moderation. Rangda and her entourage danced at the crossroads at midnight, and shortly afterward, people everywhere fell victim to a contagious illness. Many died. The king sent soldiers to kill her; however, she spewed forth fire from her eyes, nostrils, ears, and mouth, killing the soldiers. The widow incensed at the king's actions, and, with her book and followers, she went to the graveyard again. Foreswearing moderation, she danced upon and desecrated the interred bodies, thus pleasing Durgha. Widespread destruction followed. The king then called upon the assistance of his priest, Mpu Bharada, who devised a strategy. The only way that the priest could counter the disaster was to obtain and read the widow-witch's palm leaf book. The priest's pupil, Mpu Bahula, would ask for the widow's hand in marriage. It was successful. After some time, this son-in-law managed to get his wife to give him Rangda's book of magic invocations. He gave the book to his guru priest, Mpu Bharada, who then had the power to control life and death. He found the manuscript contained only the teachings of good conduct and religion; however, Rangda subverted these by 'going to the left, towards defilement.' He managed to resurrect the victims of the widow who had not yet decomposed, and he conquered the widow and then revived her, exorcizing and liberating her soul."

Following Douglas's (1966) idea of pollution, Parker (2002) argues that women, through their bodily functions, have greater access to the means of sorcery. Women as daughters, wives, mothers, and widows are more likely than men to be rendered ritually impure, vulnerable to bewitchment, and wielding ambiguous power (Parker 2002). Women have access to the placenta and after-effects of childbirth, which are the tools of sorcerers. Parker (2002) \& Geertz (1994) imply that men traditionally served as midwives because the Balinese believe that men are more powerful than women at warding off sorcery. For comparison, another way of looking at the role that men play in childbirth is to configure them into Bali's more egalitarian parenting structure. Both parents fulfill the newborn's physical, emotional, and spiritual needs, as it is not considered an exclusively female task. The parental pair participates in all of the rites of passage for their child. These rituals are geared towards providing offerings to the four spirit siblings who accompany the child at birth and help decide the child's fate as it grows into adulthood (Lansing 1995:34-35). The first three months of life is when the child is most susceptible to witchcraft. If a witch can find a way to steal the placenta, she can use it to create an invisible vampire spirit to attack her enemies. She grows the invisible vampire by feeding in on each of the spirit siblings; however, the spirit siblings have a preponderance of positive qualities nurtured and developed through the rituals surrounding childhood. This cultural belief system is still practiced today (Lansing 1995:35).

Some significant cultural differences separate and set apart the Balinese story of Rangda, the witch, and other Southeast Asian vampire myths from Spain and Portugal. There are distinct differences in how gender relations have been historically constructed in regional Southeast Asia compared to Spain and Portugal and Europe. From the European colonial perspective of the Dutch who colonized Indonesia and the British who gained hegemony over Malaysia, and the Spanish who dominated the Philippines, a woman's place was considered home. She was seen as the natural caregiver of children. The common theme of Spanish vampire folklore implies that female revenants, particularly those who have died as a result of childbirth, return to prey on children. In some ways, this might be taken to imply that Euro-colonial men felt powerless over the product of their ancestral line and/ or over the birthing process that represents a threat to their continued relationship with their wives.

Upon examining European vampire lore in general, male vampires are quite common, and they are frequently represented as omnivorous and hypersexual. They can prey on whomever they choose, yet oddly enough, female vampires are restricted to feeding on children. As a result, it would appear that such gruesome folklore might be viewed as being highly reflective of the originating culture's gender roles. Within the European context, the female domain is centered on childbirth and childcare. The masculine role might be viewed as the rational governor of a woman's actions. 
Even a cursory look at Balinese widow witchlore and the Philippine and Malaysian witch-tales reveals some significantly different Southeast Asian cultural patterns and configurations of sex and gender compared to those of European witch stories. The Philippine Aswang displays a particular set of characteristics that resemble some of the traits of Spanish and Portuguese witchlore. The Aswang is a normal woman of considerable beauty by day; however, at night, she can transform herself into a horrible flying "half-bodied" female monster, which takes flight. She then preys on the unsuspecting, sleeping population as a food source focusing on infants or pregnant women. Through a long tongue, she sucks out the blood, viscera, and even the fetus. Compared to the first Spaniard's images of witches, the similarities found include the aspect of flying, feasting on children and/or drinking blood, being horrible to see, operating primarily in the dark of night, and being unsuspected by day.

Bruja is the Spanish name for a witch. They are often represented as living vampires, usually a female who can transform themselves into various kinds of animals. They are generally reported as primarily attacking children. Another creature found in Portugal is much more like the Aswang. The Bruxa, also female, is represented as being human by day and a bird by night. It sucks the blood of children (Bunsun 2000); however, these examples represent the limit of the similarities. The Spanish witches are not viewed as beautiful at any specific time. On the contrary, she is most often represented as an ugly hag; however, she flies only through the use of a magic broom or the application of a magical ointment. Aside from the Bruxa, she usually has no means of flight due to some remarkable anatomical peculiarity. Her means of going undetected is not so much through the use of disguise, as with the Aswang; however, through the image of being a helpless old lady. It suggests that the Aswang myth probably derived from Southeast Asia's pre-colonial context rather than Spain. At the same time, it corroborates Menez's argument that the Spanish friars manipulated and used local myths to undermine the power and prestige of Philippine priestesses (Menez 1996).

By contrast, in the socially and culturally diverse contexts of island Southeast Asia, traditionally, men and women's gender roles are sometimes not rigidly applied, and women have long since enjoyed more equality with men than their early counterparts in the patrilineal societies of Europe. The female undead of the Philippines, Malaysia, Indonesia, and other areas of this region represented their sexual appeal primarily as a disguise. The creature's goal and function do not indicate that hypersexuality is an innate aspect of its character, nor is it a necessary means of attack. While male vampires exist in Southeast Asia, they are rare and do not play the same role as their European counterparts. For example, the male Bajang of Malaysia appears as a cat; however, unlike the European vampires, it seeks explicitly out children, much like the female vampires do. It seems to imply that there is some corresponding equality in folklore and the more generous gender equality in real life.

The real fear of the Europeans may be based on the fear of uncontrollable women. In contrast, the fear in regional Southeast Asia may be something or someone who may represent a danger to their children. A dangerous person from a Southeast Asian perspective maybe someone who represents a physical threat, however, who has succumbed to worldly vices and can thereby mislead their children. Thus the mythical traditions stemming from Southeast Asia and Europe are distinctly different and contrasting theoretical bases. The various European witch tales' pertinent origins trace back to the hysterical witch hunts and inquisitions of Medieval times. In contrast, the Southeast Asian tales may have something to do with metaphors to teach children how to resist worldly vices such as selfishness, greed, jealousy, or lust for power, thereby transforming themselves into nurturing human beings.

\section{Conclusion}

In conclusion, witches from the traditional Southeast Asian perspective may represent the many forces of vice in the world. In the focal case of Hindu Bali, rituals continue to be performed to transform these potentially dangerous and chaotic forces into virtuous individual and social actions. The Barong represents the culmination of the four spirit children who accompany a human child throughout his or her lifetime. It is to children's inner spirit, associated with the four cardinal directions in the world's physical realm, that the Balinese make offerings throughout the child's development into adulthood. This paper contends that Southeast Asian witch stories are moored on an entirely different 
etymological and philosophical foundation than those of Europe. While European witch tales tend to diminish women's power and voice by according them a subservient role to that of men, transposing them into sexual objects for men's pleasure and downgrading women as hags when they grow old, this not the case in Southeast Asian witchlore. Southeast Asian witches seem to represent the spirits when unbound. Witches are the culmination of worldly vices, while children growing up in a culture of respect, learn to model virtuous behavior.

\section{References}

Armstrong K (1994) A History of God: The 4,000-Year Quest of Judaism, Christianity, and Islam. New York: Ballantine Books.

Bateson G \& Mead M (1942) Balinese Character, a Photographic Analysis. New York: Academy of Sciences.

Belo J (1949) Trance in Bali. New York: Columbia University Press.

Darmini NK (2013) Textiles, Animism, and Mepetik Ceremony in Bali. [Accessed 29 May 2020]. https://www.threadsoflife.com/bali/.

Diringer D (1948) The Alphabet: A Key to the History of Mankind. New York: South Asia Books.

Douglas M (1966) Purity and Danger: An Analysis of Concepts of Pollution and Taboo. New York: Routledge and K. Paul Ltd.

Geertz H (1994) Images of Power: Balinese Paintings Made for Gregory Bateson and Margaret Mead. Honolulu: University of Hawaii Press.

Lansing S (1995) The Balinese. California: Harcourt Brace and Company.

Monaghan P (1993) The Book of Goddesses and Heroines. Saint Paul, Minnesota: Llewellyn Publications.

Parker L (2002) The power of letters and the female body: Female literacy in Bali. Women Studies International Forum 25 (1):79-96. https://doi.org/10.1016/S0277-5395(02)00218-2.

Menez H (1996) Explorations in Philippine Folklore. Manila: Ateneo de Manila Press.

Nadeau K (1993) Dissertation fieldnotes, based on fieldwork observations and interviews conducted in Philippines (1993-1994). Unpublished.

Nadeau K (2011) Aswang and other kinds of witches: A comparative analysis. Philippine Quarterly of Culture and Society 39 (3/4):250-266.

Picard M (1990) Cultural Tourism' in Bali: Cultural Performances as Tourist Attraction. Indonesia 49 (1990):37-74. https://doi.org/ 10.2307/3351053.

Phalgunadi IGP (1991) Evolution of Hindu Culture in Bali from Earliest Period to Present Time. India: Sundeep Prakashan.

Reid A (1988) Southeast Asia in an Age of Commerce, 1450-1680: Vol. 1. Lands Below the Winds. New Haven: Yale University Press.

Reid A (2015) A History of Southeast Asia: Critical Crossroads. New Jersey: Wiley Blackwell.

Sargeant W (1994) The Bhagavad Gita. In: Chapple CK (ed). New York: State of New York Press.

Smith TM (2018) The Tale of Teeth, Tell Development, Evolution, Behavior. Boston: MIT Press.

Three Worlds of Bali (1979) Documentary. Directed by Ira R Abrams \& Michael Ambrasino. Bali: Educational Resources. 